\title{
FILOSOFI WIRAUSAHA PROFETIK; SEBUAH REFLEKSI DALAM MERINTIS WIRAUSAHA DEWASA INI
}

\section{Juhanis}

\section{Universitas Islam Negeri (UIN) Alauddin Makassar}

\begin{abstract}
:
The interpreneur is basically one of the keys of an economic indefendent. Everyone has dream to be successful in this case. So that, in earlier Islam had paid intention and regulated for managing an economic inprovement. In this artcile aimed at presenting the Muhammad's consept of enterpreneur. He undoubtedly becomes a refrence of many live problems, but just very few Muslim Scholars' article which elaborates his success as an interpeneurer. It is extremely different with Western scholars that concern to examine Muhammad's success in trade. By historcial approach, the writer concludes that the key of Muhammad's success in improving his interpeneur really has a high relation of his a good attitude, aspecially honestly (al-amanah), clever (al-fatanah), (altabligh) and (al-siddiqh). Prophet Muhammad's manegement based on these attiudes becomes known as the most succesfull an interpeneruer in the world.
\end{abstract}

KeyWords: Entrepreneurship, honesty, Muhammad, manejemen

\begin{abstract}
Abstrak:
Interpreneur pada dasarnya adalah salah satu kunci ekonomi yang tidak sah. Setiap orang punya impian untuk sukses dalam hal ini.Oleh karena itu, pada awalnya Islam telah membayar niat dan diatur untuk mengelola ekonomi yang tidak efisien. Dalam artiloskop ini bertujuan untuk menyajikan konsep Muhammad tentang wiraswasta. Dia tak diragukan lagi menjadi cerminan banyak masalah, tapi hanya sedikit artikel Cendekiawan Muslim
\end{abstract}


202 |Rausyan FiKR, Vol. 13 No. 2 Desember 2017: 201-224

yang menguraikan kesuksesannya sebagai perantara. Hal ini sangat berbeda dengan sarjana Barat yang peduli untuk meneliti keberhasilan Muhammad dalam perdagangan. Dengan pendekatan historis, penulis berkesimpulan bahwa kunci keberhasilan Muhammad dalam meningkatkan interpenuously memiliki sikap baik tingkat tinggi, terutama al-amanah, al-fatanah, al-tabligh dan al-siddiqh). Manuver Nabi Muhammad SAW yang didasarkan pada attiud ini dikenal sebagai interpersonal paling sukses di dunia.

Kata kunci: Wirausaha, kejujuran, profetik, manejemen.

\section{PENDAHULUAN}

Dewasa ini, peradaban akan selalu dikendalikan oleh penguasa ekonomi. Negara yang berkuasa adalah negara yang memegang kendali perekonomian.Amerika Serikat sebagi negara super power sekarang ini karena menguasai sektor ekonomi. Belakang ini, muncul China sebagai negara yang sedang meroket dalam perekonomian.Ia pun menjadi salah satu negara yang diperhitungkan oleh negara-negara lain sekarang ini. Ia menjadi kiblat perekonomian modern. Tak lama pun peradaban akan berada dalam kendalinya, karena kaki peradaban salah satunya berpijak di at as pondasi perekonomian.

Fakta di atas mengharuskan tiap negara terus meningkatkan sektor ekonomi. Di samping karena negara mempunyai kewajiban mengsejahterakan rakyatnya, wibawa sebuah negara sedikit banyak juga diperangaruhi oleh kekuatan ekonominya. Dan salah satu caranya adalah menumbuh-kembangkan sektor perdagangan atau wirausaha.Wirausaha merupakan penopang terkuat pengembangan sektor ekonomi. 
Juhanis, Filosofi Wirausaha Profetik... 203

Kesadaran ini pun membuat para ilmuan selalu memunculkan konsep ekonomi modern, di antranya konsep wirausaha yang terus diteorisasikan.Sehinga, berbagai konsep wirausahapun bertebaran dalam buku-buku yang tersusun rapi di rak perspustakaan.Namun ada satu hal yang menarik perhatian dalam pembahasan ini, yaitu masih minimnya kajian yang melirik konsep Islam tentang wirausaha.Masih terkesan bahwa Islam hanya mengurusi urusan akhirat, tidak mengurusi hal-hal yang sifatnya duniawi.Padahal dalam sejarah kenabian, Rasulullah Saw telah lama memberikan konsep dasar wirausaha yang sangat modern.Rasululullah tidak hanya sekedar teoritis dan konseptor, tapi justru beliau terjung langsung memperaktekkan sebuah konsep wirausaha yang paling sukses yang pernah ada.Ia pun menjadi referensi bagi orang Barat. Namun sayangnya, orang Muslim sendiri belum banyak yang mengkaji secara serius konsep wirausaha Rasulullah Saw.

Dengan kenyataan ini, penulis melihat sangat urgen untuk menampilkan kembali sisi lain dari kehidupan Rasulullah. Bukan hanya Nabi Muhammad tampil sebagai seorang Rasul dan pembawa hidayah agama Islam, tapi yang tak kalah pentingnya adalah mengkaji sosok Nabi Muhammad sebagai seorang enterpeneur yang handal.Karena selama ini, kebanyakan kajian tentang sosok Nabi Muhammad ditinjau dari keberhasilan beliau sebagai Nabi, yang telah sukses membawa agama penyalamat dari masa jahiliyah ke masa yang gemilang dan beradab.

Kajian ini akan semakin penting jika melirik kondisi ril umat Islam yang semakin tertinggal dari segala aspek, termasuk dari segi perekonomian. Indonesia sebagai negara muslim terbesar, diharapkan kembali menjadi salah satu pintu untuk mengembalikan kejayaan Islam dari segi ekonomi. Tidak perlu lagi terus menghayal 
akan kembalinya the golde age yang telah lalu, tapi terpenting sekarang adalah membangkitkan semangat kerja dan usaha umat Islam dengan menjadikan Nabi Muhammad sebagai refrensi utama. Usaha ril menjadi kunci kejayaan.

Pada akhirnya, dalam kajian ini, akan mengupas konsep dan prinsip wirausaha yang Islami dengan berbasis pada cara dagang Nabi Muhammad, yang kemudian dielaborasi dengan teoriteori modern untuk memabangun wirausaha yang sukses. Sementara pendekatan yang digunakan dalam kajian ini adalah pendekatan analisa historis.

\section{MENDEFINISIKAN WIRAUSAHA}

Sebagaimana lazimnya, sebuah kajian akan dimulai dengan pengetahuan yang jelas tentang objek yang akan dikaji. Oleh karenanya, perlu untuk memaparkan pandangan ilmuan tentang definisi wirausaha.Di antaranya adalah Feter F. Ducker menyatakan bahwa kewirausahaan merupakan kemampuan dalam menciptakan sesuatu yang baru dan berbeda. ${ }^{1}$ Pernyataan di atas mensinyalir bahwa seorang wirausahawaan selalu dituntut dan ditantang untuk terus melakuakan inovoasi-inovasi yang kreatif yang menjadi pembeda dengan barang atau temuan orang sebelumnya. Ungkapan yang hampir sama oleh Zimmerer bahwa kewirausahaan menjadi salah satu proses penerapan kreativitas dan inovasi dalam memecahkan masalah dan menemukan peluang untuk memperbaiki kehidupan (usaha). Pandangan yang tidak jauh berbeda dengan pendapat yang pertama.Keduanya menekankan pada tingkat jiwa kreativitas dan inovator para wirausaha sebagai salah satu kunci kesuksesan sebuah usaha atau bisinis.

${ }^{1}$ Lihat Kasmir, S.E, M.M., Kewirausahaan, (Jakarta: PT Raja Grafindo Persada, 2008), h. 17 
Juhanis, Filosofi Wirausaha Profetik... 205

Maka dari itu, seorang wirausahawan harus memiliki kemampuan untuk terus menemukan dan menciptakan ide-ide kreatif, sebagai upaya membuka peluang usaha baru dan menjaga kompetetif secara profesional.Apalagi di era globalisasi yang serba canggih, persaingan dalam bisnis sangatlah ketat dan menantang. Di samping karena perdagangan bebas yang mana hampir tidak ada batas antara satu negara dengan negara yang lain, juga diperketat oleh canggihnya tekhnologi yang secara bersamaan mempermudah network bisnis sekaligus menantang. Mempermudah karena pemasaran dan iklan bisa dilakukan melalui via elektronik dan dunia maya, tapi juga menantang karena persaingan sangatlah tinggi.Seorang harus benar-benar bisa memanfaatkan peluang dan melakukan kreasi-kreasi baru yang bisa menarik perhatian dan minat para konsumer.

Sementara Quraisy Syihab menyatakan bahwa kata wirausaha mempunyai banyak padanan kata.Dalam bahasa Inggris sering diistilahkan buyying and selling, commerce, trade yang bermakna jual beli, perniagaan perdagangan.Pada intinya, wirausaha atau bisnis adalah interaksi antara dua pihak dalam bentuk tertentu guna meraih manfaat.Namun dalam interaksi tersebut dibutuhkan menejmen yang baik untuk meminimalisir kemungkinan resiko yang ditimbulkan.Masih menurut Quraisy Syihab bahwa dalam bahasa Arab interaksi semacam itu disebut dengan muamalah, yang dalam kajian figh Islam dikenal dengan fiqh muamalah. ${ }^{2}$

\section{TERMA WIRAUSAHA DALAM AL-QUR'AN}

${ }^{2}$ M. Quraisy Syihab, Berbisnis Dengan Allah, Cet. II (Tangerang: Lentera Hati, 2008), h. 6. 
Berbicara tentang Wirausaha, seperti yang telah disinggung di atas, terkesan sangat bersifat duniawi semata.Hanya mengurusi urusan perut dan keuntungan semata.Tapi, ternyata persepsi tersebut tidak sealur dengan logika Alquran. Justru Alquran yang selalu memberikan motivasi agar manusia terus melakukan usaha untuk mendapatkan labah dan keuntungan yang halal. Motivasi Alquran tentang etos kerja, termasuk di dalamnya bisnis dalam wirausaha, sangatlah banyak. Di antaranya dalam surah al-Jum'ah ayat 10 menegaskan bahwa setelah menunaikan salat jum'at maka bertebaranlah di muka bumi mencari karunia Allah Swt. Dalam ayat yang lain, Allah menegaskan bahwa Ia tidak akan merubah nasib satu kaum (umat) kecuali dia sendiri merubah nasibnya. Bahkan sebaliknya, Alquran sangat mengecam orang yang selalu bermalas-malasan, tidak melangkah dan berusaha mencari reski yang telah disediakan oleh Allah swt.

Begitupula dengan Rasulullah Saw., ia sangat menekankan kerja keras dalam kehidupan ini.Ia melarang ummatnya hanya berpangku tangan, mengharap rezki dengan doa saja. Dalam sebuah riwayat Nabi bersabda, "Apabila kalian selesai salat subuh, jangan kalian tidur dan malas mencari rizki". (HR Thabarani). Hal itu juga dikuatkan dengan kisah Umar bin Khattab dalam sebuah riwayat, ia memerahi seorang sahabat yang terus tinggal diam di mesjid berzikir setelah melakukan ibadah, bertawakkal kepada Allah tanpa ada usaha nyata. ${ }^{3}$

Dalam Alquran ada beberapa kata yang menunjukkan secara tidak langsung kepada istilah wirausaha atau dagang. Sebagaimana yang dipaparkan oleh Muhammad Tholhah Hasan bahwa dalam Alquran terdapat 360 ayat Alquran yang berbicara tentang "al-

${ }^{3}$ Prof. Dr. H. Buchari Alma, Kewirausahaan, cet. XIII ( Bandung: AlPABETA, 2008), h. 256. 
Juhanis, Filosofi Wirausaha Profetik... 207

amal", 109 ayat tentang "al-fi' 'i"l, dan "al-kasb" 67 ayat serta "assa'yu" sebanyak 30 ayat. Semua ayat tersebut menyinggung tentang kerja dan usaha.Masih menurut Tholhah bahwa ayat di atas tidak hanya memberikan konotasi pada amal yang bersifat ibadah mahdoh saja, tapi juga menyangkut amal atau kerja yang bersifat iqtishadiyah (ekonomis) dan ijtima'iyyah (sosial). Salah satu ayat yang menyinggung tentang ekonomi adalah Q.S al-Jum'ah: 10: "Jika selesai menjalankan shalat, maka berterbarlah di muka bumi, dan (kerjalah) mencari reski Allah..”.Dalam ayat tersebut, Allah mengaitkan langsung antara kerja (amal) yang bersifat ritual seperti salat dengan kerja yang bersifat komersial. ${ }^{4}$

Beda halnya denga Tholah di atas, M.F. Zenrif dalam bukunya "Di bawah Cahaya Alquran; Cetak Biru Ekonomi Keluarga Sakinah" lebih khusus memaparkan bahwa konsep bisnis dalam Alquran bisa dianalisa dari kata-kata bay' dan tijarah. Dalam bahasa Arab, kata ba'a, yabi'u, bay'an wa mabi'an secara leksikal bermakna memberikan sesuatu kepada seseorang dengan mengambil harga darinya. Orang yang memberikan disebut $b a ' i$ sedangkan barang yang diberikannya disebut mabi.,

Dalam Alquran kata ba'y disebutkan enam kali; 1 kali dalam QS al-Baqarah 2: 254, 2 kali dalam QS al-Baqarah 2: 275, 1 kali dalam QS Ibrahim 2: 31, 1 kali dalam QS al-Nur. 24: 37, dan 1 kali dalm QS al-Jum'ah .62: 9. Dari semua ayat tersebut mengandung makna jual beli.Namun jika diperhatikan secara lebih mendalam, misalnya melihat hubungan antar kata dan prase dalam ayat di atas, ayat-ayat tersebut terkadang bermakna lebih sekedar

${ }^{4}$ Muhammad Tholhah Hasan, Islam \& Masalah Sumber Daya Manusia, cet. IV ( Jakarta: Lantabora Press, 2005), h 238-239.

${ }^{5}$ Louis Ma'luf, Al-Munjid (Beirut: Dar al-Masyriq, 1987), h 56. 
jual beli; yaitu kata $b a^{\prime} y$ berkonotasi makna sosial, persahabatan yang dibangun di atas pondasi kasih sayang dan bahkan pertolongan.Hal ini mengindikasikan bahwa jual beli sangat mulia.Di dalamnya terdapat interaksi horizontal yang sangat agung.Di antaranya adalah membangun silaturrahim antara sesama, saling membantu memenuhi kebutuhan masing-masing dan tentunya adalah saling mendapat keuntungan.

Sementara kata kedua yang menunjukkan pada usaha dan bisnis adalah tijarat. Secara leksikal, tijarat berasal dari kata tajara, tajran wa tijaratan yang bermakna jual beli yang bertujuan mendapatkan keuntungan. Dalam kamus Arab- Indonesia, kata tersebut diterjemahkan dengan perdagangan, perniagaan dan bisnis. ${ }^{6}$ Kata tijarah disebutkan sebanyak 9 kali, dan tijarat disebutkan 8 kali, sementara dalam bentuk frase tijratahum disebutkan 1 kali. $^{7}$

Sedangkan dalam istilah fiqh, kata di atas menunjukkan pada sistem pertukaran barang dengan uang yang diperbolehkan agama untuk dipergunakan atau dimanfatkan. ${ }^{8}$ Sementara Imam Hanafi menyatakan bahwa ba'y adalah pertukaran harta dengan harta dengan carakhusus, atau pertukaran barang yang dibutuhkan dengan cara tertentu, yakni dengan penerimaan dan pemberian. Hampir senada dengan Imam Nawawi yang mendefinisikan sebagai

${ }^{6}$ Atabik Ali dan Ahmad Zuhdi Muhdlor, Kamus Kontemporer Arab Indonesia, (Yogyakarta: Yayasan Ali Maksum, 1996), 406.

${ }^{7}$ Muhammad Fuad Al-Baqi, Al- Mu'jam al-Mufahras li al-Fadz alQur'an al- Karim (Beirut: Dar al- Fikr, 1987), h. 152.

${ }^{8}$ Taqyuddin Abi Bakr Muhammad al-Husainy, Kifayat al-Akhyar fi Hill Ghayat al-Ikhtishar, Juz I (Bandung: Syirkah al-Ma'arif wa al-Nasyar, t.th), h. 239. 
Juhanis, Filosofi Wirausaha Profetik... 209

sebuah kegiatan pertukaran harta milik seseorang dengan harta milik orang lain. ${ }^{9}$

Senada dengan Tholah, Prof Jusmaliani dkk dalam bukunya "Bisnis Berbasis Syariah" menyatakan bahwa dagang atau perdagangan sebagai konsep sangat penting dalam Islam.Di antara bukti pentingnya konsep tersebut ketika Alquran memakai istilah tersebut yang multimakna. Kata perdagangan tidak hanya digunakan untuk menunjuk pada aktivitas transaksi dalam pertukaran barang atau produk tertentu pada kehidupan nyata dalam sehari-hari, tapi juga ditunjukkan pada sikap ketataan seseorang pada Allah Swt. Dalam arti lain bahwa perdagangan mencakup pengertian eskatalogis, yaitu dagang yang bersifat ibadah. ${ }^{10}$

Pandangan di atas memberikan gambaran bahwa kehidupan nyata ini memang berdimensi ganda; dimensi dunia dan akhirat.Berdimensi dunia apabila seorang hanya meletakkan tujuan hidupnya berhenti pada kehidupan dunia itu sendiri. Tidak percaya kehidupan setelah dunia ini fana.Tidak percaya pada hari kebangkitan dan pembalasan.Begitupula sebaliknya kehidupan ini terlihat bedimensi akhirat jika hanya dilihat dari sisi ritual akhirat seperti salat, puasa dsb. Tapi sebenarnya Islam tidak menghendaki umatnya memilih satu dari dua dimensi di atas, karena Islam memberi ruang umatnya untuk memiliki dimensi dunia dan akhirat secara bersamaan.Dalam hal ini, Islam menganjurkan untuk memilih kehidupan dunia yang berdimensi akhirat. Dengan demikian, dengan pilihan tersebut seseorang tidak hanya akan

${ }^{9}$ Wahbah Zuhaily, Al-Fiqh al-Islamiy wa Adillatuh, Juz IV, Cet. III, (Damasyiq: Dar al-Fikr, 1989), h. 344-345

${ }^{10}$ Prof. Jusmaliani M.E, dkk, Bisnis Berbasis Syariah, cet. I ( Jakarta: Bumi Aksara, 2008), h. 24 
mendapat kebaikan dalam kehidupan di akhirat kelak, tapi juga akan mendapat kebaikan di dunia yang sedang dialami (QS. AsySyura 42: 20. Dalam konteks ini, dagang ataupun usaha bisnis akan bernilai ibadah jika hal itu dikerjakan dalam rangka ketaatan kepada Allah Swt. ${ }^{11}$ Dalam sebuah hadist juga hal itu dikuatkan oleh Sabda Rasulullah Saw. bahwa berdagang itu adalah sebuah kegiatan yang dilakukan dalam rangka mencari ridha Allah Swt. dengan cara berbuat baik kepada sesama manusia. Sebagaimana dalam sebuah hadist menyatakan "Sekali-kali tidaklah seorang mukmin akan merasa kenyang (puas) mengerjakan kebaikan, sampai puncaknya ia memasuku surga”. (HR. Tirmidzi).

\section{WIRAUSAHA PROFETIK ALA MUHAMMAD SAW.}

Dalam kajian keislaman, sosok Nabi Muhammad Saw.adalah tokoh sentral dan sebagai refrensi utama dalam segala hal, baik itu terkait dengan persoalan ekonomi, sosial kemasyarakatan maupun ia sebagai seorang pemimpin perang yang gagah berani. Namun, ada satu hal yang masih kurang dikaji oleh para intelektual muslim dulu dan kontemporer, yaitu aspek Muhammad Saw. sebagai wirausahawan yang sukses. Kelihaiannya dalam menejemen membuatnya ia sangat disegani dalam rekan bisnisnya. Dalam usia 40 an ia sudah sukses sebagai seorang trader yang sangat sukses. Namun, sisi itu seakan hilang dari sentuhan kajian para intelektual Muslim.

Di akhir tahun tujuh puluhan, kajian tentang kewirausahan/enterpreneurship mulai dikaji kembali di negara Eropa, Amerika bahkan Asia, termasuk Indonesia sebagai negara Islam terbanyak di dunia. Salah satu kajian yang menarik tentang kewirausahaan yaitu kajian David Moors dalam bukunya The

\footnotetext{
${ }^{11}$ Ibid., h. 25.
} 
Enterprising.Ia mengungkapkan bahwa ciri-ciri wirausaha adalah mengenai personality dan pelaku wirausaha itu sendiri, di samping lingkungan yang mendukungnya, juga tugas-tugas yang diemban oleh seorang wirausaha dan karir yang bisa dicapainya. Lebih lanjut katanya, 'The act of enterpreneurship is an act patterned after modes of coping with early childhood experiences'.Personality atau kepribadian seorang wirausaha adalah sikap yang didapatkannya sejak masa kecil yaitu sikap merdeka, bebas dan percaya diri. ${ }^{12}$

Ketiga sikap ini sangat dipengaruhi oleh lingkungan kedua orang tua di mana peran ibu yang begitu penuh dedikasi terhadap perkembangan anaknya sangat berpengaruh.Pengaruh dari kedua orang tua juga bisa sangat menunjang atau bahkan merusak salah satu atau ketiga unsur kepribadian wirausaha seorang anak. Viktor Kiam, seorang pakar enterpreneur, sama berkomentar bahwa jiwa enterpreneur/wirausaha perlu diberikan kepada anak sejak dibangku sekolah, karena filosofi kewirausahaan dapat melatih anak lebih mandiri, jeli melihat peluang, sehingga punya daya cipta yang lebih kreatif. $^{13}$

Terkait dengan konsep di atas, tenyata ribuan tahun yang lalu telah ada dalam diri seorang Muhammad.Dia adalah wirausahawan yang memiliki kemerdekaan dan kepercayaan diri yang tinggi. Hal itu terbentuk dari proses dan pengalaman hidup yang ia lalui. Dalam sejarahnya, ia lahir seorang yatim dan ditinggal ibunya ketika masih berumur enam tahun. Ia pun diasuh oleh kakenya, Abdul Muttalib. Namun tak lama bersamanya, ia pun

${ }^{12}$ M. Thobrani, Super Sukses Muhammad, cet. I (Yogyakarta:

Cakrawala, 2011), h. 161.

${ }^{13}$ M. Thobrani, Super Sukses Muhammad,..h. 161. 
harus berpisah dengan sang kakek di usia delapan tahun, dua bulan, sepuluh hari. Pada akhirnya, ia pun dibesarkan oleh pamannya, Abu Thalib sampai ia dewasa dan menerima amanah kenabian dan kerasulan. ${ }^{14}$ Kondisi tersebut kemudian membentuk karakter dan psikologis yang kokoh sebagai modal utama dalam berwirausaha di kemudian hari. Bahkan para wirausahawan modern seperti David Moores dan Orvis Colins, Abaham Zaleznik, Jhon Kao sebagai refrensi dalam penelitian mereka.

Pada dasarnya, Nabi Muhammad dari sejak kecil telah dikenal sebagai orang terpercaya (al-Amin). Tidak hanya itu, ia juga dikenal dengan kecerdasannya (fathonah), kejujuran (asSiddiq) dan kesetiaannya memegang janji (amanah). Dengan karakter tersebut, ia pun mendapat kepercayaan dari para pemilik modal. Ketika itu, adalah Khadijah sebagai pemegang modal pun memberikan tawaran untuk menjalin mitra kerja sama dalam membangun bisnis yang berdasarkan pada sistem bagi hasil (profit sharing) atau mudarabah. ${ }^{15}$

Muhammad pun mulai dikenal sebagai seorang wirausahawan. Namanya mulai dikenal di Syiria, Yaman, Basra (Iraq), Yordania dan kota-kota metropolitan di Jazirah Arabiyah. Dengan semangat suka sama suka dan kejujuran dan profesionalisme membuatnya ia semakin disenangi oleh mitra bisninya. Dan secara tidak langsung, ia pun telah berhasil menanam benih etika dasar dalam wirausaha yang kemudian menjadi refrensi hingga dewasa ini.

\footnotetext{
${ }^{14}$ Syekh Shafiyyur Rahman al-Mubarakfury, Sirah Nabawiyah, ter. dari Ar-Rahiq al-Makhtum oleh Kathur Suhardi, cet VIII (Jakarta: Pustaka al-Kautsar, 2000), h. 79-80.
}

${ }^{15}$ M. Thobrani, Super Sukses Muhammad,..h. 162 
Juhanis, Filosofi Wirausaha Profetik...| 213

\section{PRINSIP DASAR WIRAUSAHA PROFETIK}

Kesuksesan seoarang Muhammad dalam merintis usaha bisnisnya, tak lepas dari kerja keras dan manejemen serta marketing yang sangat profesional. Dengan demikian, perlu dielaborasi lebih lanjut prinsip-prinsip dasar cara dagang ala Muhammad agar menjadi refrensi untuk mengembangkan segala usaha baik mikro maupun usaha secara makro dewasa ini.

Sehubungan dengan itu, sebagaimana jamak diketahui bahwa landasan moral dan tingkah laku Nabi Muhammad adalah Alquran.Segala tindak tanduk dalam kesehariannnya selalu menecerminkan ajaran moral Alquran, termasuk etika bisnisnya. Kaitannya dengan poin ini, Quraisy Syihab pun menyimpulkan secara umum bahwa sebuah bisnis yang sukses tak lepas dari tiga elemen dasar. Pertama, berkaitan dengan hati/kepercayaan pebisnis; kedua, berkaitan dengan moral dan perilaku pebisnis; ketiga, berkaitan dengan harta/perolehan keuntungan. ${ }^{16}$

M. Quraisy Syihab lebih lanjut memaparkan bahwa seorang penugasaha harus mempunyai niat (visi) yang baik.Usaha atau bisnis tidak hanya sekedar mengejar keuntungan semata. Tidak juga hanya untuk memperkaya diri, tapi usaha yang kita rintis harus menjadi sarana untuk saling membantu dalam memenuhi kebutuhan orang lain. Dan pada akhirnya, bisnis yang demikian itu, akan bernilai ibadah bahkan sebagian daripada jihad. ${ }^{17}$ Dalam

\footnotetext{
${ }^{16}$ M. Quraisy Syihab, Berbisnis Dengan Allah, Cet. II (Tangerang: Lentera Hati, 2008), h. 13.

${ }^{17}$ Muhammad Ali Haji Hashim memaparkan mengarang satu buku yang berjudul Bisnis satu cabang JIHAD. Dalam buku tersebut beliau memaparkan bahwa dengan bisnis kita bisa membantu orang yang terkena musibah, meringankan beban hidup orang lemah. Ia pun mengutip majalah Businesswee akhir tahun 2002 bahwa 50 orang pengusasaha dan pewirausaha paling dermawan
} 
214 |RAusyan FiKR, Vol. 13 No. 2 Desember 2017: 201-224

sebuah hadis Rasulullah Saw. disebutkan, "Seorang Mukmin memperoleh ganjaran menyangkut segala sesuatu, walaupun menyangkut sesuap yang dipersembahkannya ke mulut istrinya (HR. Ahmad).

Begitupula dengan moral pembisnis, menurutnya, harus memperlakukan mitranya sebaik-baik mungkin. Tidak saling merugikan (la darar wa la dirara). Hal ini tidak berarti bahwa pembisnis tidak mementingkan laba (keuntungan), bahkan Islam sangat menekankan keuntungan dalam bisnis, tapi hal itu bukan satu-satunya tujuan utama. Pebisnis juga harus melihat sisi yang lain daripada sekedar keuntungan secara materil, yaitu keuntungan non material yang bersifat kepuasan batin. Hal itu yang diistilahkan oleh Ippho Santosa Spritual Investment. ${ }^{18}$

Di samping itu, aturan dalam pengembangan harta juga tidak luput dari aturan Islam.Prinsip kehalalan, manfaat, sukarela, kejelasan, keseimbangan, dan persaingan sehat adalah hal-hal pokok yang mesti diperhatikan oleh pembisnis dalam melakukan transaksi dalam jual beli. ${ }^{19}$ Konsep-konsep di atas telah diperaktekkan oleh Muhammad dalam hidupnya selama 25 tahun sebelum kenabian.Ia pun, dalam kurung waktu yang relatif singkat, menjadi sangat sukses dan dikenal sebagai mellioner di seluruh kota metropolitan kala itu.

di dunia. Di antaranya Bill Gates, pemilik Microsoft menyumbang sebanyak US\$ 25.6Bilion, terutama dalam bentuk obat-obatan dan vaksi untuk puluhan ribu anak-anak miskin di India dan Afrika. Lihat, dalam Bisnis Satu Cabang Jihad,Cet. I (Jakarta: Al-Kautsar, 2005), h. 206-207.

${ }^{18}$ Ippho Santosa, Muhammad Sebagai Pedagang, Cet ke 11, (Jakarta: PT Elex Media Komputindo, 2011), h. 66.

${ }^{19}$ M. Quraisy Shihab, Berbisnis..h. 23-24. 
Juhanis, Filosofi Wirausaha Profetik... 215

Dan untuk lebih detailnya M. Thobrani dalam bukunya "Super Sukses Muhammad" juga membahas kunci kesuksesan bisnis Nabi Muhammad.

Pertama, ditinjau dari sistem Marketing Nabi.Menurutnya, Nabi Muhammad menjadikan kejujuran sebagai asas dalam sebuah bisnis.Tidak hanya kelebihan barangnya yang dijelaskan kepada pembeli tapi juga kekurangan-kekurangannya (cacat).Takaran timbangan yang sangat adil. Ia pun dikenal sebagai al-Amin (orang terpercaya), yang pada akhirnya kepercayaan (trust) dari mitra bisnisnya tak lagi diragukan yang menjadi kunci dalam sebuah bisnis.

Kedua, melayani dengan sepenuh hati. Selain jujur, pelayanan yang baik juga menjadi kunci kesuksesan Rasulullah.Ia pun memperlakukan istimewa kepada semua orang. Ia sangat ramah dan murah hati kepada pembeli. Akhirnya semua pembeli merasa senang dan sangat merasa terhormat jika berinteraksi dengan Rasulullah Saw.Hal itu juga dikatakan oleh Beliau, "Belum beriman seseorang sehiangga dia mencintai saudaramu seperti mencintai dirimu sendiri".

Ketiga, memenuhi janji. Dalam berbisnis, Nabi Muhammad selalu tepat janji. Baik janji antar pribadi, antar kelompok maupun antar negara. ${ }^{20}$ Hal itu sebagai bentuk akhlak Al-Qur'an yang menganjurkan untuk selalu menepati janji (Q.S Al-Maidah: 5: 1) “ Hai orang beriana, penuhilah akaq-akad itu..”Begitupula dalam pemasaran barang, beliau selalu menepati pesanan pembeli, dan menyediakan barang sesuai dengan yang ada dalam iklan.

\footnotetext{
${ }^{20}$ Prof. Dr. Yunahar Ilyas, MA, Cakrawala Al-Qur'an; Tafsir Tematis tentang Berbagai Aspek Kehidupan, Cet. II (Yogyakarta: Itqan Publishing, 2009), h. 189.
} 
Keempat, tidak ada sumpah palsu.Sumpah palsu adalah fenomena yang sering kita saksikan dalam transaksi jual beli.Penjual terkadang bersumpah demi meyakinkan para pembeli. Hal ini tentu tidak sealur dengan cara dagang Rasulullah Saw. Ia tidak pernah sumpah demi menarik perhatian dan kepercayaan orang lain. Bahkan beliau dalam sebuah riwayat sangat mewantiwanti cara dagang dengan melakukan sumpah palsu. Ia bersabda, "Dengan melakukan sumpah palsu, barang-barang memang terjual, tetapi hasilnya tidak berkah". Dalam hadis lain, hadis riwayat Abu Zar Rasulullah Saw mengancam dengan azab pedih bagi orang yang bersumpah palsu dalam bisnis, dan Allah tidak akan memperdulikannya nanti di hari kiamat (H.R Muslim).

Kelima, ada unsur sosialnya. Hal yang menarik dan berbeda dari dagang Rasulullah Saw. adalah bisnis yang tidak hanya sekedar memikirkan keuntungan secara materi semata, tapi lebih daripada itu, Rasulullah juga sangat bahkan mengedepankan unsur sosial. Dalam hal ini, tidak terlalu menonjolkan keuntungan secara materi, tapi juga mengedepankan prinsip saling tolong menolong. Hal itu terjadi dengan dua cara, yaitu dengan menjual hal-hal yang sangat dibutuhkan oleh orang lain, dan kedua dengan harga yang terjangkau. Hal itu yang dikatakan oleh Prof Dawan Raharjo bahwa reski itu bersifat sosial, baik dalam proses produksi, distribusi maupun komsumsinya. ${ }^{21}$

Keenam, tidak memonopoli perdagangan.Salah satu yang selalu menjadi perhatian Rasulullah Saw. adalah melarang para pedagang memonopoli perdagangan. Monopoli dalam perdagangan secara otomatis berdampak pada permainan harga. Pembeli juga terkadang merasa terpaksa membeli barang yang ia butuhkan

\footnotetext{
${ }^{21}$ Prof. Dr. M. Dawan Raharjo, Ensiklopedi Al-Qur'an; Tafsir Sosial Berdasarkan Konsep-konsep Kunci, Cet. II (Jakarta: Paramadina, 2002), h. 591.
} 
Juhanis, Filosofi Wirausaha Profetik... 217

dengan harga yang tinggi, karena tidak ada barang yang lain. Tentu kondisi semacam ini sangat bertolak belakang dengan prinsip dasar dagang Rasulullah Saw. yaitu saling suka sama suka, tidak ada unsur paksaan dan terpaksa (la darar wa la dirar). ${ }^{22}$

\section{MERINTIS WIRAUSAHA SUKSES}

Setelah menelaah sejarah perjalanan karir Nabi Muhammad dalam mencapai puncak kesuksesan bisnisnya, maka tampak jelas dalam diri Muhammad tampil sebagai pewirausa yang sangat sukes. Maka dari itu, alangkah naifnya jika orang Barat telah menjadikannya sebagai refrensi dalam kajian mereka, sementara kita sebagai orang Islam hanya diam berpangku tangan. Dengan demikian, pada poin ini penulis akan mengejawantahkan rahasia bisnis Nabi Muhammad Saw yang kemudian dielaborasi dengan konsep atau teori wirausaha modern untuk mencapai usaha yang menjanjikan.

Prof. Dr. Bukhari Alma, dalam bukunya "Kewirausahaan", memaparkan salah satu bab pembahasan adalah Jalan Menuju Wirausaha Sukses. Ia pun mengutip Murphy and Peck (1980: 8) tentang delapan anak tangga untuk mencapa puncak karir, yaitu kerja keras, penampilan baik, keyakinan yang kuat, pandai mengambil keputusan, terus menambah pengetahuan, ambisi untuk maju, komunikasi yang baik. Dari delapan konsep itu jauh sebelumnnya Rasulullah telah memperaktekkan dalam bisnisnya.

\footnotetext{
${ }^{22}$ M. Thobrani, Super Sukses Muhammad, Cet. I (Yogyakarta: Cakrawala, 2011), h. 170-171
} 
218 |RAusyan FiKR, Vol. 13 No. 2 Desember 2017: 201-224

\section{a. Mau Kerja Keras (Capicity for Hard Work)}

Kerja keras adalah kunci utama kesuksesan seorang pengusaha.Tanpa kerja keras, seorang hanyalah bermimpi untuk menjadi orang sukes. Dalam sejarah, Islampun sangat membenci orang yang malas berkerja, dan orang yang hidup mengemis serta tergantung pada orang lain. Nabi dalam kisahnya, pernah memberi hadiah kapak dan tali kepada seorang lelaki agar ia memakai kedua alat tersebut untuk mencari kayu demi memenuhi kebutuhan sehari-harinya. Umar pun demikian, dalam sebuah riwayat, pernah menegur dan memarahi seorang sahabat yang hanya duduk diam dala masjid setelah salat.

Selain itu, sejarah Rasulullah telah mengajari kita betapa pentingnya sebuah kerja keras.Rasulullah telah melintasi banyak negara dari Mekkah ke Syria dan beberapa negara tetangga.Kondisi pada saat itu pun tidak seaman sekarang. Tanah yang tandus dan padang pasir yang sangat panas menjadi tantangan tersendiri untuk melintasi satu kota. Namun, dengan kerja keras dan semangat yang tinggi hal itu telah dilewatinya dengan modal semangat. Tidak sama dengan kondisi para saudagar dan pebisnis dewasa ini, rintangan tidak terlalu sulit, bahkan pasilitas yang ada semakin mempermudah segalanya. Hanya duduk diruangan ber-AC, bisa mengunjungi satu negara ke negara lain dalam waktu yang cukup singkat. Tidak seperti dulu yang mana Nabi Muhammad hanya memakai unta bahkan jalan kaki melintasi padang pasir untuk memasarkan dagangannya.

b. Bekerjasama dengan Orang Lain (Getting Things Done With and Through People)

Banyak teman banyak reski. Slogan itu sangatlah tepat dalam mengembangkan bisnis.Seorang pebisnis diharpakan untuk 
terus memperbanyak teman dan menghindari permusuhan. Dalam konteks ini, pebisnis diharuskan untuk bertingkah ramah dan dan menjaga kepercayaan orang lain. Di samping itu ia juga harus memiliki kepiawaian menggerakkan orang lain, yang mana hal itu disebut sebagai salah satu bentuk dari manejmen, yaitu seni menggunakan tenaga orang lain untuk mencapai tujuan yang telah ditetapkan. Semuanya bisa tercapai di atas, bila sifat pebisnis tersebut memperlakukan orang lain sebaik-baik mungkin. Memperlakukan orang lain seistimewa mungkin tanpa membedabedakan antara orang miskin, kaya, atau orang pejabat. Kita harus membuat mereka merasa seorang raja yang segala kebutuhannya dilayani oleh pelayanannya.

Sehungan dengan konsep di atas, sebenarnya jauh sebelumnya Nabi telah memberikan kata kunci kesuksesan sebuah usaha. Dalam sejarahnya, Rasulullah dikenal dengan sangat ramah dan pintar bergaul dengan siapa pun.Ia juga sangat disenagangi oleh semua orang. Tak ada musuhnya.Bahkan silaturrahimnya sangat kuat.Maka tak salah jika Rasulullah dalam satu riwayatnya menyatakan bahwa, "Barangsiapa yang ingin dilapangkan rezkinya maka hendaklah menyambung silaturrahimya".

c. Penampilan yang Baik (Good Appearance)

Penampilan yang baik tidak hanya sekedar paras muka yang cantik, elok dan sebagainya, tapi yang paling penting adalah penampilan yang baik yang dimaksud adalah kepribadian yang agung, seperti jujur, ramah dan murah senyum. Dewasa ini, para pembisnis terkadang memahami penampilan yang baik dengan kurang arif.Penampilan yang baik hanya terbatas pada penampilan para saleswomen yang tampil seksi dan menawang, tapi terkadang tidak terlalu memerhatikan kejujurannya.Maka hal itu, untuk 
jangka pendek, bisa saja berhasil menarik perhatian banyak orang, tapi tidak bertahan lama.

Dalam tataran inilah yang membedakan bisnis Rasulullah Saw. Dalam kisahnya, Rasul juga sangat rapi, bahkan disebutkan dalam sirah, Nabi Muhammad tidak pernah pisah dari sisir dan cerminnya, bahkan ketika ia bangun dari tidurnya, langsung merapikan rambutnya agar ia selalu tampil menarik. Selain, itu kejujuran Rasulullah merupakan daya tarik yang sangat luar bisa pengaruhnya dalam menarik simpatik para pembeli, ditambah lagi dengan muka yang selalu ceria dan murah senyum. Dalam perakteknya, Rasulullah saw yang selalu menyapa dan menyalami para pembeli.

\section{d. Yakin (Self Confidence)}

Percaya diri adalah keyakinan yang besar untuk sukses. Seorang pebisnis harus ia yakin bahwa ia kan sukses dalam usahanya. Ia pun harus menjauhkan segala sifat keraguan dalam bisnisnya. Maka dari itu, dalam Islam tiap langkah dan usaha yang diharapkan dimulai dengan niat yang baik, dalam bahasa manejemenya adalah visi yang jelas. Dengan jelasnya niat (visi) ke depan maka hal itulah yang akan membuat kita selalu optimis dalam melalui proses pencapaian. Sehingga, dalam keseharian, seorang pebisnis pun selalu tekun, sabar melalui ringtangan serta tidak memperdulikan pendapat-pendapat yang bisa melemahkan semangatnya.Ia terus maju melangkah dengan percaya diri.

e. Pandai Membuat Keputusan (Making Sound Decision)

Mengambil keputusan yang tepat juga menjadi hal yang sangat urgen dan menentukan dalam kesuksesan sebuah usaha.Cepat dan tepat.Tidak hanya cepat, tapi juga harus tepat 
Juhanis, Filosofi Wirausaha Profetik... 221

sasaran. Begitu banyak orang yang bangkrut karena salah dalam mengambil keputusan. Dengan demikian, kematangan dalam menimbang sesuatu sangat diperlukan sebelum memutuskan sesuatu. Tidak boleh tergesa-gesa, namun juga tidak boleh terlalu lambat. Sekali lagi, cepat dan tepat. Rasulullah Saw. telah memberikan keputusan yang tepat dan cepat dalam sejarahnya.

\section{f. Pandai Berkomunikasi}

Komunikasi adalah alat yang paling asasi untuk menjalin hubungan dengan orang lain. Pandai berkomunikasi adalah piawai mengorganisasi buah pikiran ke dalam bentuk ucapan yang jelas, dan enak didengar dan mampu menarik perhatian orang lain. Keterampilan berkomunikasi juga termasuk modal utama untuk bisa menjadi orang besar, apalagi menjadi seorang bisnisman. Komunikasi baik menjadi kunci kemampuan seorang manejer menggerakkan bawahannya, begitupula sebaliknya, seorang bawahan dengan sesamanya atau dengan atasannya harus menjaga komunikasi yang baik.

Dalam sirah kenabian, komunikasi yang baik telah dicontohkan oleh Rasulullah Saw sendiri. Tiap orang yang berkumunikasi dengannya selalu merasa enak dan terhormat.Orang tidak pernah tersinggung oleh kata-kata Rasulullah Saw. Di samping itu, semua orang dengan berbagai latar belakang, baik orang kaya, bangsawan, rakyat biasa, orang miskin, merasa bahwa apa yang disampaikan oleh Rasulullah sesuai dengan kebutuhannya. Hal itu dikenal dalam sejarah bahwa Rasulullah saw seorang penyampai pesan (al-tabligh). Pesan yang disampaikannya benar-benar sampai dan dipahami secara jelas orang yang mendengarkannya. Kunci dari semua itu adalah Rasulullah Saw memberikan orang lain apa yang ia butuhkan. Di saat berhadapan dengan orang bangsawan, beda komunikasi yang ia gunakan jika 
222 |Rausyan Fikr, Vol. 13 No. 2 Desember 2017: 201-224

berhadapan dengan orang bisa. Begitupula di depan para orang kaya juga berbeda pola komunikasi di hadapan orang miskin.

\section{KESIMPULAN}

Wirausaha adalah bagian dari ibadah, bakan salah satu dari cabang jihad. Olehnya, wirausaha sangatlah mulia dalam Islam. Dengan berwirausaha, seseorang akan mandiri dan tidak akan menjadi beban hidup kepada orang lain. Ia pun akan selalu memberi dan menolong orang-orang yang membutuhkan. Realitas ini sangatlah dijunjung tinggi dalam Islam.Tangan di atas lebih baik daripada tangan di bawah.Kondisi ini pun bisa dicapai dengan berwirausaha. Maka dari itu, tidaklah benar persepsi yang berkembang bahwa harta itu adalah hina.Dalam banyak literatur Islam menunjukkan harta sangatlah mulia. Manusia secara fitrah diberi cinta akan harta, ia pun dikaruniai oleh Allah Swt kemampuan untuk menjemput harta (reski). Bahkan Dalam sejarah, Rasululla Saw sebagai guru yang paling bijak dalam persoalan wirausaha. Di usia yang masih belia, telah merintis usaha, dan penjadi pengusaha/enterpreneur handal yang sangat terkenal di Jazirah Arab kala itu.

Wirausaha ala Rasulullah Saw telah menjadi contoh dan refrensi dunia sekarang ini.Bahkan ada sekian data mensinyalir bahwa dari sekian banyak konsep dan teori wirausaha modern telah lama diperaktekkan oleh Nabi Muhammad.Salah satu contoh tersebut adalah kejujuran.Kejejuran inilah yang menjadi modal utama dalam sebuah bisnis.Dari kejujuran terciptalah sebuah saling kepercayaan (trust) yang merupakan kunci utama dalam membangun mitra dan mengembangan bisnis.Pada akhinya, wirausaha sangatlah mulia. Apalagi wirausaha yang berpijak pada caraRasulullah. Tidak hanya mementingkan keuntungan materi, 
Juhanis, Filosofi Wirausaha Profetik... 223

tapi yang tak kalah pengingnya adalah keuntungan inmateri, yaitu kepuasan batin (investment spritual).

\section{DAFTAR PUSTAKA:}

Kasmir, S.E, M.M. Kewirausahaan. Jakarta: PT Raja Grafindo Persada, 2008.

Syihab, M. Quraisy. Berbisnis Dengan Allah, Cet. II. Tangerang: Lentera Hati, 2008.

Alma, Buchari Alma. Kewirausahaan, cet. XIII, Bandung: AlPABETA, 2008.

Hasan, Muhammad Tholhah. Islam \& Masalah Sumber Daya Manusia, cet. IV. Jakarta: Lantabora Press, 2005.

Ma'luf, Louis. Al-Munjid. Beirut: Dar al-Masyriq, 1987.

Ali, Atabik Ali dan Ahmad Zuhdi Muhdlor. Kamus Kontemporer Arab Indonesia. Yogyakarta: Yayasan Ali Maksum, 1996.

Al-Baqi, Muhammad Fuad. Al- Mu'jam al-Mufahras li al-Fadz alQur'an al- Karim. Beirut: Dar al- Fikr, 1987.

Al-Husainy, Taqyuddin Abi Bakr Muhammad. Kifayat al-Akhyar fi Hill Ghayat al-Ikhtishar, Juz I. Bandung: Syirkah al-Ma'arif wa al-Nasyar, t.th.

Zuhaily, Wahbah. Al-Fiqh al-Islamiy wa Adillatuh, Juz IV, Cet. III,. Damasyiq: Dar al-Fikr, 1989.

Jusmaliani M.E, dkk. Bisnis Berbasis Syariah, cet. I. Jakarta: Bumi Aksara, 2008.

Thobrani, M. Super Sukses Muhammad, cet. I. Yogyakarta: Cakrawala, 2011.

Al-Mubarakfury, Syekh Shafiyyur Rahman. Sirah Nabawiyah, ter. dari Ar-Rahiq al-Makhtum oleh Kathur Suhardi, cet VIII. Jakarta: Pustaka al-Kautsar, 2000.. 
224 |RAusyan FiKR, Vol. 13 No. 2 Desember 2017: 201-224

Hasyim, Muhammad Ali Haji. Bisnis Satu Cabang Jihad, Cet. I. Jakarta: Al-Kautsar, 2005.

Santosa, Ippho. Muhammad Sebagai Pedagang, Cet ke 11. Jakarta: PT Elex Media Komputindo, 2011.

Ilyas, Yunahar. Cakrawala Al-Qur'an; Tafsir Tematis tentang Berbagai Aspek Kehidupan, Cet. II Yogyakarta: Itqan Publishing, 2009.

Raharjo, M. Dawan. Ensiklopedi Al-Qur'an; Tafsir Sosial Berdasarkan Konsep-konsep Kunci, Cet. II. Jakarta: Paramadina, 2002. 